\title{
Psychological Process of Travel Destination Choice
}

\author{
Richard TR Qiu $^{\mathrm{a}}$, Lorenzo Masiero ${ }^{\mathrm{a}}$ and Gang $\mathrm{Li}^{\mathrm{b}}$

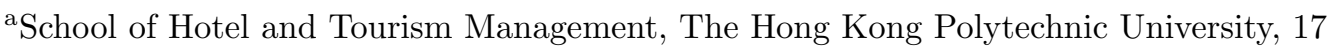 \\ Science Museum Road, TST East, Kowloon, Hong Kong SAR.; \\ ${ }^{\mathrm{b}}$ School of Hospitality and Tourism Management, University of Surrey, Guildford, Surrey, \\ GU2 7XH, United Kingdom.
}

\begin{abstract}
This paper reviews literature on travel destination choice and organizes these studies systematically. A "cell-system" structure is proposed to describe the psychological process of travel destination choice. In forming decisions on vacations, tourists gather information on potential destinations and evaluate visit intentions among potential destinations ("cell"). The visit intentions are successively compared while information is updated in the process ("system"). The "cell-system" structure provides a clear view of the psychological process of travel destination choice. Empirical studies nested on the structure can provide further insights into why and how tourists choose travel destinations.
\end{abstract}

\section{KEYWORDS}

Travel destination choice; Psychological process; Visit intention evaluation; Visit intention comparison; Choice formation

\section{Introduction}

The choices of travel destinations have attracted considerable attention from scholars from several disciplines, including tourism, economics, and sociology. Many studies within the tourism research context have focused on how psychological factors affect tourists' decisions on travel destinations (Dann, 1981; Plog, 1974; Um \& Crompton, 1990; Woodside \& Lysonski, 1989).

Plog (1974) first introduced tourist psychographics system into tourism research (Leung \& Law, 2010). Since then, many studies have been conducted based on the proposition that "different types of people tend to choose different travel destinations" (T. H. Lee \& Crompton, 1992; Plog, 1974). These studies establish the linkage between different personality traits and the final choice of travel destinations. Considerable

CONTACT Richard TR Qiu. Email: richard.tr.qiu@connect.polyu.hk

The paper should be cited as follows:

Qiu, R.T.R., L. Masiero and G. Li (2018). The psychological process of travel destination choice. Journal of Travel \& Tourism Marketing, DOI: 10.1080/10548408.2018.1435332. 
research has focused on the proposition that "people with different purposes tend to choose different travel destinations" (Dann, 1981; Kozak, 2002; Moscardo, Morrison, Pearce, Lang, \& O'Leary, 1996). These studies investigated how travel motivation influences tourists' final choice of travel destination. Previous studies have also focused on the logical process by which a finite set of potential travel destinations was reduced down to a final choice (Ajzen \& Driver, 1992; Um \& Crompton, 1990; Woodside \& Lysonski, 1989).

This paper reviews studies that investigate each element of the travel destination choice mechanism. The relevant literature is gathered through desk research based on Google Scholar search engine, with "destination choice" and "tourist behavior" as main key words. The identified journal articles and their reference lists are used for the review. The reviewed studies all investigate specific aspects of destination choices, focusing either on the psychological formation of visit intentions or on the process that leads to the choice of a destination. The current study proposes a novel conceptual framework for destination choice by combining the two streams of research. In particular, the results of the review are integrated to develop an extended framework for destination choice, namely the "cell-system" structure that systematically links together all the aspects of the destination choice process. Different streams of the literature are blended together so that the "cell-system" structure will not only provide insights into the role of various factors in the entire destination choice process but also reveal the interactions among factors from different parts and stages of the destination choice process. The framework proposed in this paper has two layers. Theory of planned behavior is used to link psychological factors to the final selection of travel destinations. The inner layer, which is defined as the "cell", represents tourists' evaluation of each destination and the formation of visit intention. The choice set framework is used to compare different destinations and reduce the choice set at each stage of the destination choice process. This outer layer, which is referred to as the "system", along with the previous one, is jointly referred as the "cell-system" structure. This structure will capture the entire process, beginning from the moment that a tourist decides to go on vacation to the moment that a unique destination is chosen.

The contribution of the present study is two-fold; it introduces a systematic review 
of studies employing the psychological perspective of travel destination choice and proposes a "cell-system" structure to provide a deeper understanding of the mechanism underlying travel destination choice. The study is the first to investigate the combined yet distinct effects of personality and motivation on travel destination choice by combining the following propositions: "different types of people tend to choose different travel destinations" (i.e., a personality perspective) and "people with different purposes tend to choose different travel destinations" (i.e., a motivation perspective).

\section{Literature Review}

\subsection{Objective Factors and Destination Choice Process}

Since Gorman $(1957,1980)$ and Lancaster $(1966,1971)$ developed the characteristic framework that describes consumption goods as packages of different characteristics, the study of consumption behavior was ushered into a new era. The utility gain from consuming one product can be represented as the weighted summation of utility provided by each product characteristic. Thus, travel destinations can be considered a combination of different destination attributes (Papatheodorou, 2001, 2002; Stabler, Papatheodorou, \& Sinclair, 2009). Wu, Zhang, and Fujiwara (2011) categorized the factors that influence tourists' travel destination choice into three groups. The first two groups, namely, alternative-specific factors and situational factors, are related to the permanent and temporary attributes of destinations, respectively. The third group, namely, decision maker-specific factors, are associated with tourist characteristics.

The price associated with a destination is one of the most commonly discussed attributes in the alternative-specific group; this attribute is investigated in relation to either tourism activities (Awaritefe, 2004; Eymann \& Ronning, 1997; Eymann, Ronning, \& Zimmermann, 1992) or travel cost (Morey, Shaw, \& Rowe, 1991; Seddighi \& Theocharous, 2002; Siderelis \& Moore, 1998; Train, 1998). Consistent with the law of demand in economic theory, keeping all other things unchanged, an increase in price will result in a decline in visit intention. Travel distance and travel time, which are similar to price, adversely influence visit intention (Huybers, 2003; Nicolau \& Más, 2006; Wu et al., 2011). Tourism resources or attractions in a destination 
are also important factors that influence the destination choice process (Moscardo et al., 1996). Research has proved positive relationships between visit intention and the number of tourist spots in a destination (Wu et al., 2011), type of activities available at the destination (Huybers, 2003), attractiveness (Awaritefe, 2004; Wu et al., 2011), reputation (Eymann et al., 1992), and ranking of activities in a destination (Train, 1998). Quality services provided in a destination have been asserted to be important for planning trips (Awaritefe, 2004; Siderelis \& Moore, 1998).

Unlike alternative-specific factors, situational factors include all aspects associated with a specific trip. Crowdedness (Font, 2000; Huybers, 2003), climate and weather conditions (Hamilton, 2004; Stemerding, Oppewal, \& Timmermans, 1999), and social and political situations (Fuchs \& Reichel, 2006; Seddighi, Nuttall, \& Theocharous, 2001; Sönmez \& Graefe, 1998a) are suggested to exert significant, although mostly temporary, influence on travel destination choice.

Within the third group of influential factors, the characteristics of travel party extend the consideration of travel destination from the individual level to the group level. The size and composition of a travel party will affect travel destination choice (Nichols \& Snepenger, 1988; Ritchie \& Filiatrault, 1980; Thornton, Shaw, \& Williams, 1997). Different tourist behaviors are also identified among geographical segmentations (Kim, Wan, \& Pan, 2015), socioeconomic segmentations (Swarbrooke \& Horner, 2003), and demographical segmentations, such as age (Anderson \& Langmeyer, 1982), gender (Swarbrooke \& Horner, 2003), and religious groups (Kim, Im, \& King, 2015).

\subsection{Subjective Factors and Destination Choice Process}

Subjective factors are also crucial to the travel destination choice process. In particular, personality is shown to have a significant effect on an individual's choice of travel destination. Cohen (1972) classified four types of tourists based on their desire for novelty and familiarity. The "drifter", to one extreme, demands the highest level of novelty and almost no familiarity. The "organized mass tourist", on the other end, looks for destinations with maximum familiarity and minimum novelty. The "explorer", as a weaker form of the "drifter", and the "individual mass tourist", as a weaker form of the "organized mass tourist", lay respectively between the two extremes. The concep- 
tual classification proposed by Cohen (1972) initiated an interesting stream of research about travel personality.

Plog (1974) proposed the tourist psychographics system and pioneered studies on travel personality. Tourists are categorized along a continuum into five groups, namely, "Allocentric", "Near-Allocentric", "Midcentric", "Near-Psychocentric", and "Psychocentric". "Allocentric" tourists are the "first people to 'discover' a new area" (Plog, 1995, p. 57), whereas "Psychocentric" tourists prefer familiar and mature destinations. The categories were modified into "Venturers", "Near-Venturers", "Midcentric", "Near-Dependable", and "Dependable", respectively, in the studies of Plog (1995) and Plog (2001). In its most recent form (Best Trip Choices, 2017), the "MidCentric" tourists are further divided into two categories ("Voyagers" and "Journeyers"), and the entire system is changed and has six categories, namely, "Venturers", "Pioneers", "Voyagers", "Journeyers", "Sightseers", and "Traditionals". Nickerson and Ellis (1991) extended Plog (1974)'s model by including the energy dimension ${ }^{1}$ and activation dimension. Litvin (2006) replicates Plog (1974)'s work using a sample from Singapore and found a positively skewed tourist distribution among different destinations unlike the original version of Plog (1974). Hence, Litvin (2006) argued that Plog's model categorized more of an ideal vacation rather than a realistic destination choice.

Griffith and Albanese (1996) tested Plog's instrument against three dominant personality scales: Locus of Control Scale (Rotter, 1966), Form V Sensation Seeking Scale (Zuckerman, Eysenck, \& Eysenck, 1978), and Interaction Anxiousness Scale (Leary, 1983). The results confirmed the consistency between Plog's instrument and personality scales derived from psychology literature, suggesting the efficacy of psychological personality scales in predicting destination choice. Jani (2014) related Plog (1974)'s travel personality to Big Five Factors of personality and reached similar conclusions with those of Griffith and Albanese (1996). Eachus (2004) and Lepp and Gibson (2008) adopted a brief Sensation Seeking Scale to identify tourists seeking sensation in their tourism experiences. The results indicated that sensation-seeking tourists will likely enjoy adventurous holidays. T. H. Lee and Crompton (1992) developed a "Novelty

\footnotetext{
${ }^{1}$ Initially proposed but assumed to be insignificant by Plog (1974).
} 
Seeking Scale" based on various psychology scales, such as Leisure Boredom Scale (Iso-Ahola \& Weissinger, 1990), Arousal Seeking Scale (Mehrabian \& Russell, 1973), Novelty Seeking (Maddi, Charlens, Maddi, \& Smith, 1962; Pearson, 1970; Wentworth \& Witryol, 1986), and Sensation Seeking Scale (Zuckerman, 1971, 1979; Zuckerman, Kolin, Price, \& Zoob, 1964). The resulting scale was proven effective in identifying and segmenting tourists as members of the novelty-seeking group and familiarity-seeking group.

Unlike all the studies above, Gretzel, Mitsche, Hwang, and Fesenmaier (2004) integrated a strong tourism flavor into the 12 travel personalities in their study. These travel personalities include "Culture Creature", "City Slicker", "Sight Seeker", "Family Guy", "Beach Bum", "Avid Athlete", "Shopping Shark", "All Arounder", "Trail Trekker", "History Buff", "Boater", and "Gamer".

Travel motivation represents another aspect of subjective factors that influence destination choices. Although psychology literature shows that personality can change with age or major life events (Specht, Egloff, \& Schmukle, 2011), personality is quite steady within a stable period of life (McCrae \& Costa, 1994). Instead, travel motivation is typically trip-specific.

The concept of travel motivation in tourism research is usually classified into two forces: push factor, which "deals with tourist motivation per se" (Dann, 1981, p. 190), and pull factor, which "represents the specific attractions of the destination which induces the traveler to go there..." (Dann, 1981, p. 191). In a simpler explanation, Dann (1977) described push factors as the motives that drive tourists away from home, whereas pull factors pertain to the motives that drive tourists towards a destination. Early classifications by Gray (1970) and Dann (1977) also fit into the framework. Gray (1970) divided tourists into "sunlust" and "wanderlust", with the former being "motivated by the desire to experience different..." (Crompton, 1979, p. 410) or the push factor, whereas the latter is motivated by leaving a familiar environment to see different things (Crompton, 1979) or the pull factor. Dann (1977) suggested the classification of "anomie" and "ego-enhancement" in the early stage of his "pushpull Dann period" (Jacobsen, 2016), where "anomie" is related to push factors and "ego-enhancement" is associated largely with pull factors. Push factors are commonly 
connected to internal or emotional aspects, whereas pull factors are more related to external or cognitive aspects (Yoon \& Uysal, 2005).

Several studies were conducted to link push and pull factors to the destination image, and the destination choice for tourists. Chen and Chen (2015), Hsu, Tsai, and Wu (2009), Jang and Cai (2002), Mohammad and Som (2010) found strong links between push or pull motivations and destination or activity choice. Moscardo et al. (1996) adopted cluster analysis and argued that activities in a destination were a critical link between travel motivation and destination choice. Kozak (2002) investigated push and pull motivations of tourists of different nationalities and concluded that motivations can be influenced by cultural or nationality differences. These studies generally support the proposition that "people with different purposes tend to choose different travel destinations".

All aforementioned studies provide arguments or evidence in favor of the propositions that "different types of people tend to choose different travel destinations" and "people with different purposes tend to choose different travel destinations". These studies covered many, if not all, perspectives of personality and travel motivations. Solid linkages are shown between these personality traits and travel motivation factors and the final decision of a travel destination. However, the channel through which these personality traits and travel motivation factors influence the final decision remains vague.

\subsection{Formation of Visit Intention}

Although the studies mentioned in the previous section identify the factors that influence final destination choices, a number of studies focus on the process of travel destination choice. Studies by Ajzen and Driver (1992) adopt a relatively micro perspective. Theory of planned behavior was initially proposed by Ajzen (1985) as an extension of the theory of reasoned action (Fishbein \& Ajzen, 1977) to describe and predict human behavior. The theory was later applied to tourist behavior and destination choice by Ajzen and Driver (1992), Han, Hsu, and Sheu (2010), and Lam and Hsu (2004, 2006). Three core elements are identified to influence visit intention and consequently visiting behavior: tourists' attitude toward a destination; the subjective norm 


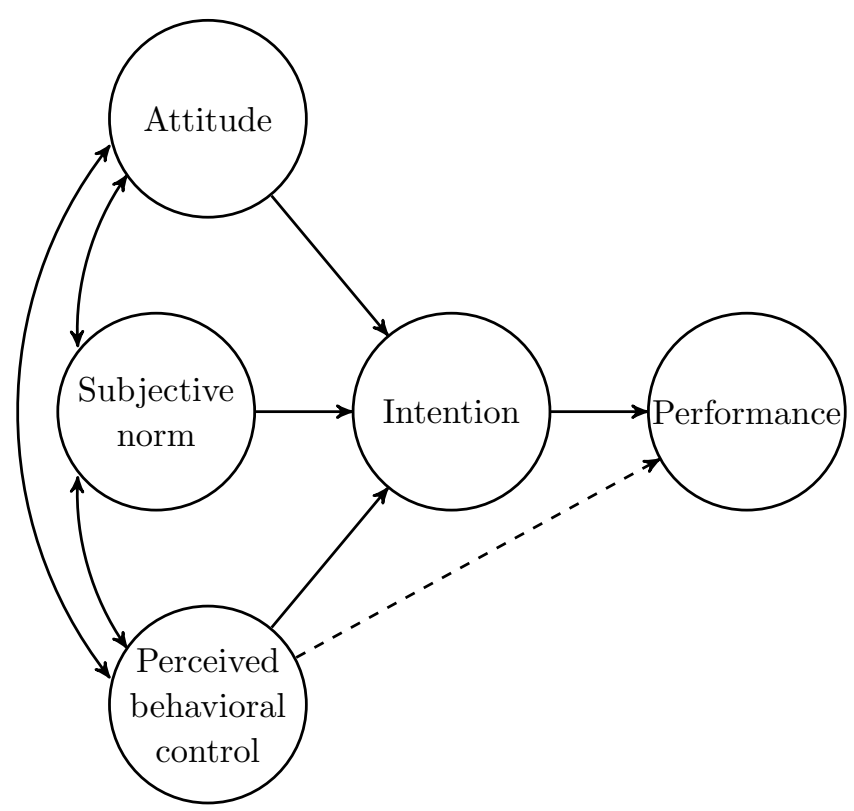

Figure 1. Theory of planned behavior (Ajzen \& Driver, 1992, p. 210)

perceived by tourists about a destination; and the behavioral control perceived by tourists about visiting a destination. Theory of planned behavior, as shown in Figure 1 , assumes that attitude, subjective norm, and perceived behavioral control collectively determine visit intention. Visit intention, together with actual control over the behavior (travel), determine performance (visiting behavior). Perceived behavioral control functions as a good substitute for actual control (Ajzen, 1985).

Although the predictive power of the theory of planned behavior has been proven, an additional step is required to compare visit intention for alternative destinations and narrow down the selection to one destination.

\subsection{A Logical Process of Destination Choice}

Woodside and Sherrell (1977) adopted the conceptual framework of evoked, inept, and inert sets from consumer behavior to describe the decision process of travel destination choice. Crompton (1992), Crompton and Ankomah (1993), Decrop (2010), Karl, Reintinger, and Schmude (2015), and Um and Crompton (1990) further developed and refined the framework. This stream of study provides a macro perspective of the destination choice process. Figure 2 shows its most recent form, which was introduced 


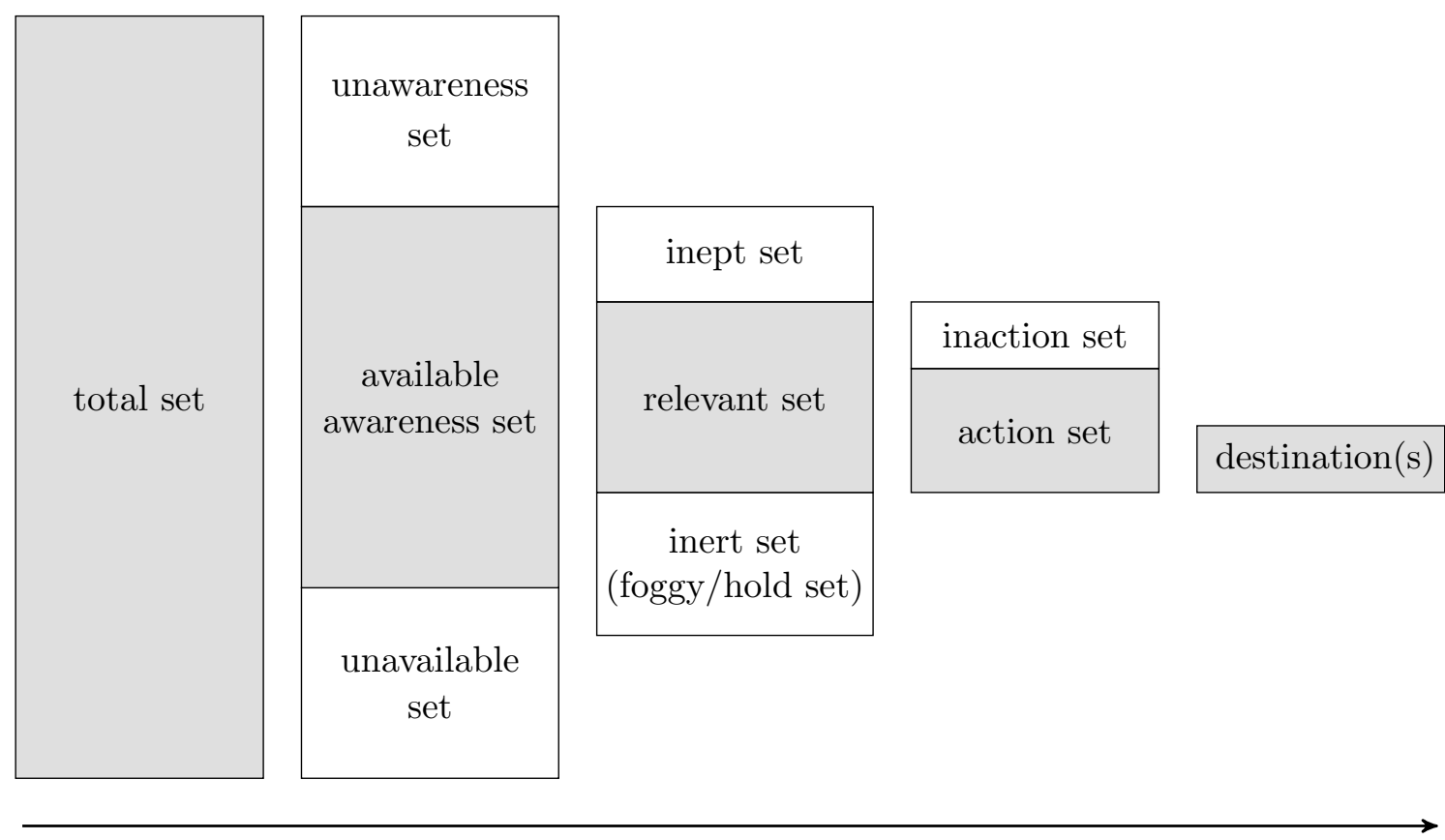

destination choice sequence

Figure 2. Destination choice set structure (Karl, Reintinger, \& Schmude, 2015, p. 49)

by Karl et al. (2015).

The total set represents all possible destinations, which are divided into three subsets: destinations of which tourists are unaware (unawareness set); destinations known by tourists but are unavailable due to certain constraints (unavailable awareness set); and destinations are known and available to tourists (available awareness set). The destinations in the available awareness set $^{2}$ are evaluated by tourists and divided into three subsets (Narayana \& Markin, 1975): destinations for which tourists have negative evaluation (inept set); destinations towards which tourists are indifferent (inert set); and destinations that tourists are willing to consider and acquire additional information on (relevant $\left.\operatorname{set}^{3}\right)$. A destination can be moved into the inept set due to unpleasant personal experiences or negative external feedback. The destinations in the inept set are generally rejected by tourists. The inert set, on the other hand, can be further divided into two subsets (Brisoux \& Laroche, 1980; Church, Laroche, \& Blatt,

\footnotetext{
${ }^{2}$ The available awareness set is also called early consideration set (Crompton \& Ankomah, 1993).

${ }^{3}$ The relevant set is also called evoked set (Crompton, 1992; Decrop, 2010; Um \& Crompton, 1990) and late consideration set (Crompton, 1992; Crompton \& Ankomah, 1993).
} 
1985): destinations for which tourists lack sufficient information to form a positive or negative evaluation but not sufficiently motivated to perform an information search (foggy set); and destinations toward which tourists are indifferent although they are knowledgeable about it (hold set). Destinations included in the inert set may still be considered for future travels. Based on the information acquired, tourists may decide not to act upon some destinations (these destinations form the inaction set, and later on become part of the inert set) or develop negative feelings about other destinations (these destinations join the inept set). The information-acquiring process ends when a final destination is chosen.

Unlike the stream of studies that adopt the theory of planned behavior, studies employing the choice set framework describe the destination choice process from a macro perspective. While the theory of planned behavior cannot easily capture the entire destination choice process, the choice set framework cannot provide details at each stage. Embedding theory of planned behavior into the choice set framework may shed light on the overall travel destination decision-making process.

\section{The "Cell"}

\subsection{Core of the "Cell"}

Theory of planned behavior is adopted to construct the core of the "cell". Tourists' attitude towards a destination, the subjective norm on the destination perceived by tourists, and the control over a trip perceived by tourists collectively determine visit intention. Empirical evidence for the above propositions can be found throughout the literature in different contexts, including the intention to visit green hotels (Han et al., 2010), participation in leisure activities (Ajzen \& Driver, 1992), and visiting tourist destinations (Lam \& Hsu, 2006). The interactions among the three elements are also supported by (Han et al., 2010) and (Lam \& Hsu, 2004).

The core of the "cell", which is a restructuring of the theory of planned behavior in the destination choice context, is illustrated in Figure 3. Supporting studies are denoted by the first letter of the last name of each author in addition to the year of publication. 


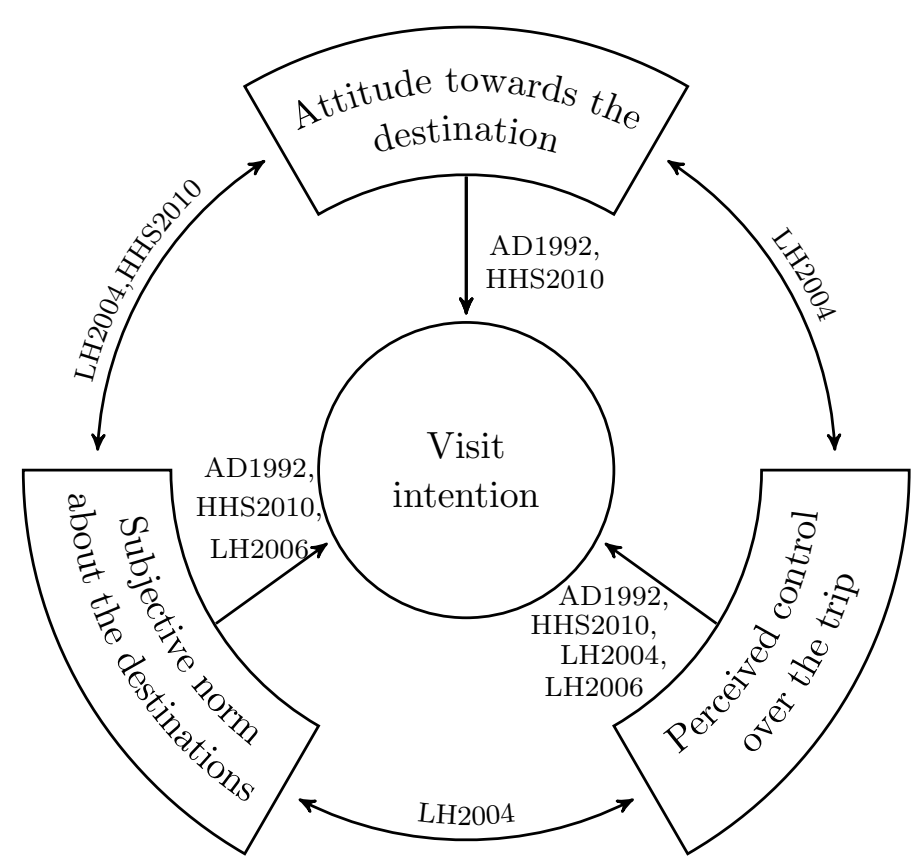

Figure 3. Core of the "cell"

\subsection{Inner Layer of the "Cell" (Subjective Factors)}

Although attitude, subjective norm, and perceived behavioral control determine visit intention, psychological factors also affect these areas. Personality and motivation are both proven to affect visit intention. However, the confusion between the two is common (Moscardo, Dann, \& McKercher, 2014).

Most studies adopt either personality or motivation or a mixture of the two to control individual differences among tourists. A combined yet distinct usage of the two appears appropriate because it allows the completion of the propositions formulated for tourist personality and motivation. In this context, the proposition "different types of tourists tend to choose different travel destinations" is completed by the proposition "same type of tourists still tends to choose different travel destinations if they have different motivation". In a similar manner, the proposition "tourists with different motivation tend to visit different travel destinations" is completed by the proposition "tourists with same motivation tend to visit different travel destinations if they have different personalities". While being paired with tourists' personality, the motivation factors adopted in studies are normally push factors that reflect internal or emotional aspects. In the current study, the term motivation (push) will be adopted to distinguish 
the term from motivation factors in general.

The influence of personality and motivation (push) on visit intention can be traced back to human nature. (Larsen \& Buss, 2013) divided personality perspectives into six domains, namely, dispositional, biological, intrapsychic, cognitive-experiential, social and cultural, and adjustment. Each domain reflects an important aspect of human nature, but the domains cannot stand alone to represent the whole person (Larsen \& Buss, 2013). The dispositional domain identifies the fundamental traits of personality, while the biological domain categorizes bodily factors that influence or are influenced by personality (Leung \& Law, 2010). These two domains focus on the influence of biochemistry or mythical unconsciousness factors on tourists' own mind. These domains affect tourists' attitude toward potential destinations through personality. The intrapsychic domain categorizes the motives within unconsciousness that influence behavior, thoughts, and feelings (Larsen \& Buss, 2013). The factors associated with the intrapsychic domain, therefore, affect tourists' attitude toward a destination through motivation (push).

Big Five Factors, a representative personality measurement from the dispositional domain, is adopted by Jani (2014) in investigating tourists in Busan, Korea. Empirical results show significant differences in Big Five Factor test scores among different types of tourists (Jani, 2014). Various versions of Sensation Seeking Scales followed the theme of the biological domain. By examining a U.S. undergraduate students' population, Zuckerman's Form V Sensation-Seeking Scale determined a positive and significant correlation with the tourist personality that described in Plog (1974) (Griffith \& Albanese, 1996). Similar results were obtained in a sample of 111 U.K. university staff and students (Eachus, 2004) and a sample of 290 college students born and raised in the U.S. (Lepp \& Gibson, 2008). Plog (1974, 2001)'s travel personality test is an approach to describe a destination choice from the intrapsychic domain. With more than 200 studies and consulting assignments, the test results show substantial power in predicting travel patterns and preferences (Plog, 2001).

The cognitive-experiential domain emphasizes people's thoughts, feelings, beliefs, and desires about oneself and others (Larsen \& Buss, 2013). In addition to its power in shaping human nature, this domain also affects motivation (push) through desires and 
perceived behavioral control by understanding experiences. Locus of Control (Rotter, 1966), which is a representative from the cognitive-experiential domain (Leung \& Law, 2010), is confirmed to improve the measurement of Plog's travel personality (Madrigal, 1995). Zimmer, Brayley, and Searle (1995) found locus of control, which pertains to the ability to handle money, to be an important predictor of destination choice among seniors in Manitoba, Canada. Pomfret (2006) asserted locus of control as one of the six motivational dimensions that are linked to mountaineering participation.

The social and cultural domain emphasizes the interrelationship between the personality of individuals and the social/cultural environment. The factors in this domain affect the personality of tourists, and these factors are affected by the subjective norm perceived by tourists, as determined (Ng, Lee, \& Soutar, 2007) in the context of cultural distance and Australian tourists' intention to visit holiday destinations.

The adjustment domain refers to the ability of people to adapt to the environment and adjust to challenges. Factors associated with this domain affect tourists' perception of their control over trips.

The six domains of human nature generally reflect subjective factors that underlie visit intention. The process of travel destination choice is a production process with the final travel destination as the output. Thus, the six domains of human nature would be the production machinery. The travel motivation factors, as a temporary arousal arises before each specific trip, are the gears in the production machinery. Different travel destinations would be selected by tourists with different travel motivations in a similar manner that different products can be produced with various sets of gears. Collectively, the human nature of personality and travel motivations form the inner layer of the "cell". Figure 4 illustrates the influence of factors from the inner layer on elements of the core of the "cell". Supporting studies are denoted in the same manner as in Figure 3. Links $\alpha$ and $\beta$ are based on the psychological definition of the social and cultural domain and the adjustment domain, respectively.

\subsection{Outer Layer of the "Cell" (Objective Factors)}

Objective factors also have a significant influence on visit intention. Information gathering, which is a thorough information search for a comprehensive choice or a simple 


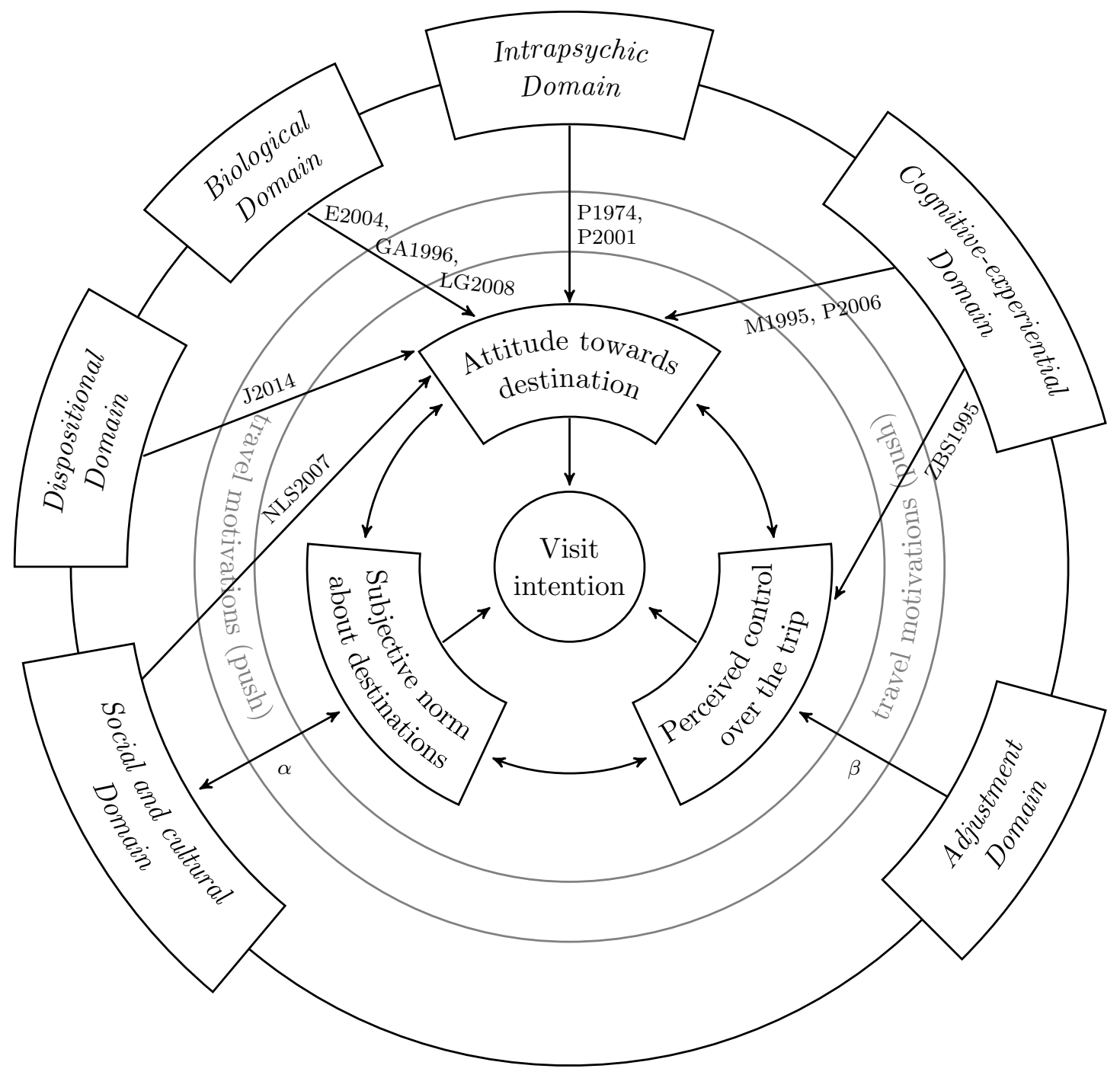

Figure 4. Inner layer of the "cell" 
memory recall for a quick decision, usually initiates the destination choice process. Primary information possessed by tourists and secondary information collected from other channels are the basis for the formation of visit intention. In particular, primary information on potential destinations is recalled from memory; secondary information may be gathered from other information channels, including Internet, television, newspaper, magazine, word of mouth, and other people's opinions. These two groups of information are external objective factors that influence tourists' attitude toward potential destinations. Information on the tourists themselves and other tourists is also collected. Together with information on potential destinations, the objective constraints are identified as a type of internal objective factors.

The psychological process of destination choice is the main focus of this paper and the effect of objective factors on visit intention is not discussed thoroughly. The objective factors interact with subjective factors and collectively influence visit intentions (Figure 5). The current literature focusing on objective factors is limited to providing evidence on the linkage between objective factors and final choice of destination and does not examine the moderating and mediating roles of the psychological process. Therefore, the studies discussed below (and listed in Figure 5) only suggest the direction of the influence rather than provide direct proof.

Tourists' knowledge on potential destinations forms the foundation of tourists' attitude toward potential destinations. Various studies on destination images focused on how information possessed by tourists influences the perception of a destination image (Beerli \& Martin, 2004; Echtner \& Ritchie, 1993). The past experience of tourists plays a crucial role in forming tourists' attitude toward potential destinations (Lam \& Hsu, 2006). Theoretical and empirical studies that apply prospect theory to destination choice can also shed light on the linkage between past experiences and attitude formation towards destinations (Smallman \& Moore, 2010). Primary information on both destination and tourists will also provide basic understanding of the perceived control over trips. Risk perceptions are strongly correlated with visit intention (Sönmez \& Graefe, 1998b). Familiarity, which will significantly influence the perception of destination image and control over trips, are also correlated with destination choice (G. Lee \& Tussyadiah, 2012). Tourists generally learn of the challenges through their knowledge 


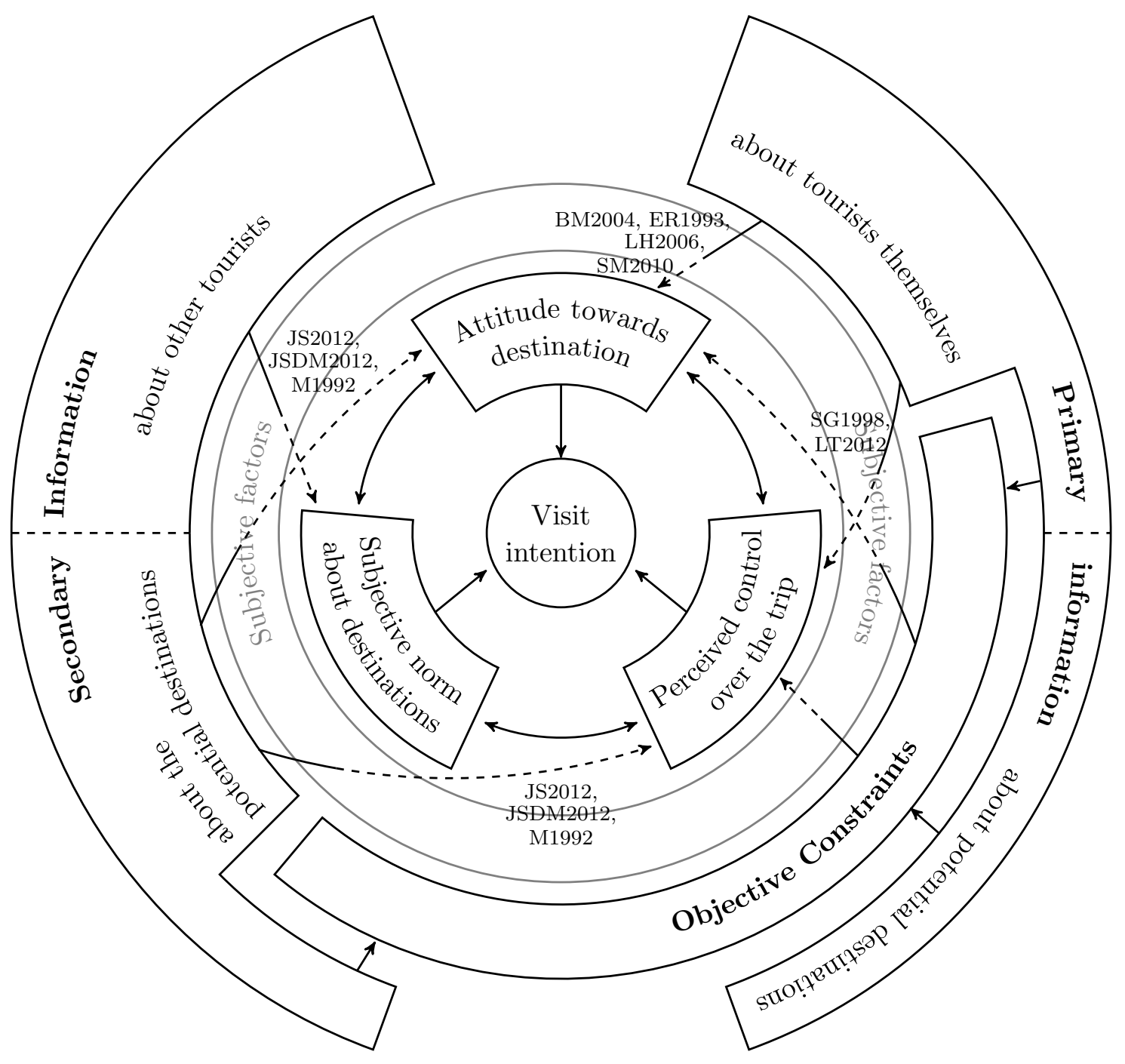

Figure 5. Outer layer of the "cell" 
and evaluate the ease of control with past experience.

Objective constraints, which are a type of internal objective factors, restrict the set of destinations available to tourists. Objective constraints can also influence tourists' attitude toward a destination and tourists' perception of control. Although average tourists consider a luxury destination to be a perk, wealthy tourists perceive luxury travel as part of their everyday life (Dykins, 2016). According to an international speaker, Stacy Speller, "If money can solve your problem, it's not a problem". This quote may not reveal the truth of life, but it indicates a relationship between budget, constraint, and ease of control. By having a fixed budget, a destination with a low budget constraint will have high fault tolerance.

Secondary information is argued to be related to visit intention and destination choice from many aspects. It influences tourists' attitude toward a destination and perceived control over trips the same way as primary information. It also provides tourists with the opinion of other people regarding potential destinations, which form the subjective norm. Mansfeld (1992) conceptualized three functions that secondary sources of information fulfilled: to create an image of a destination, to justify a choice, and to minimize risk. These three functions correspond to attitudes toward a destination, subjective norm, and perceived control over trips, respectively. Word-of-mouth, a significant source of secondary information, is found to be strongly related to visit intention and destination choice (Jalilvand \& Samiei, 2012; Jalilvand, Samiei, Dini, \& Manzari, 2012; Tham, Croy, \& Mair, 2013).

Objective information, both external and internal, forms the basis of visit intention. Subjective factors are also involved in the process. Travel motivation, in particular, is determined to exhibit a significant moderating effect on distance and prices on destination choice in Spain (Nicolau \& Más, 2006).

Figure 5 describes the outer layer of the "cell". Objective factors may influence subjective factors. In the long run, factors from the cognitive-experiential domain are generated through past experiences and the learning process; factors from the intrapsychic domain can also be affected by blocked memories through unconsciousness; factors from the social and cultural domain are largely generated from secondary information; factors from the adjustment domain can also be affected by past expe- 


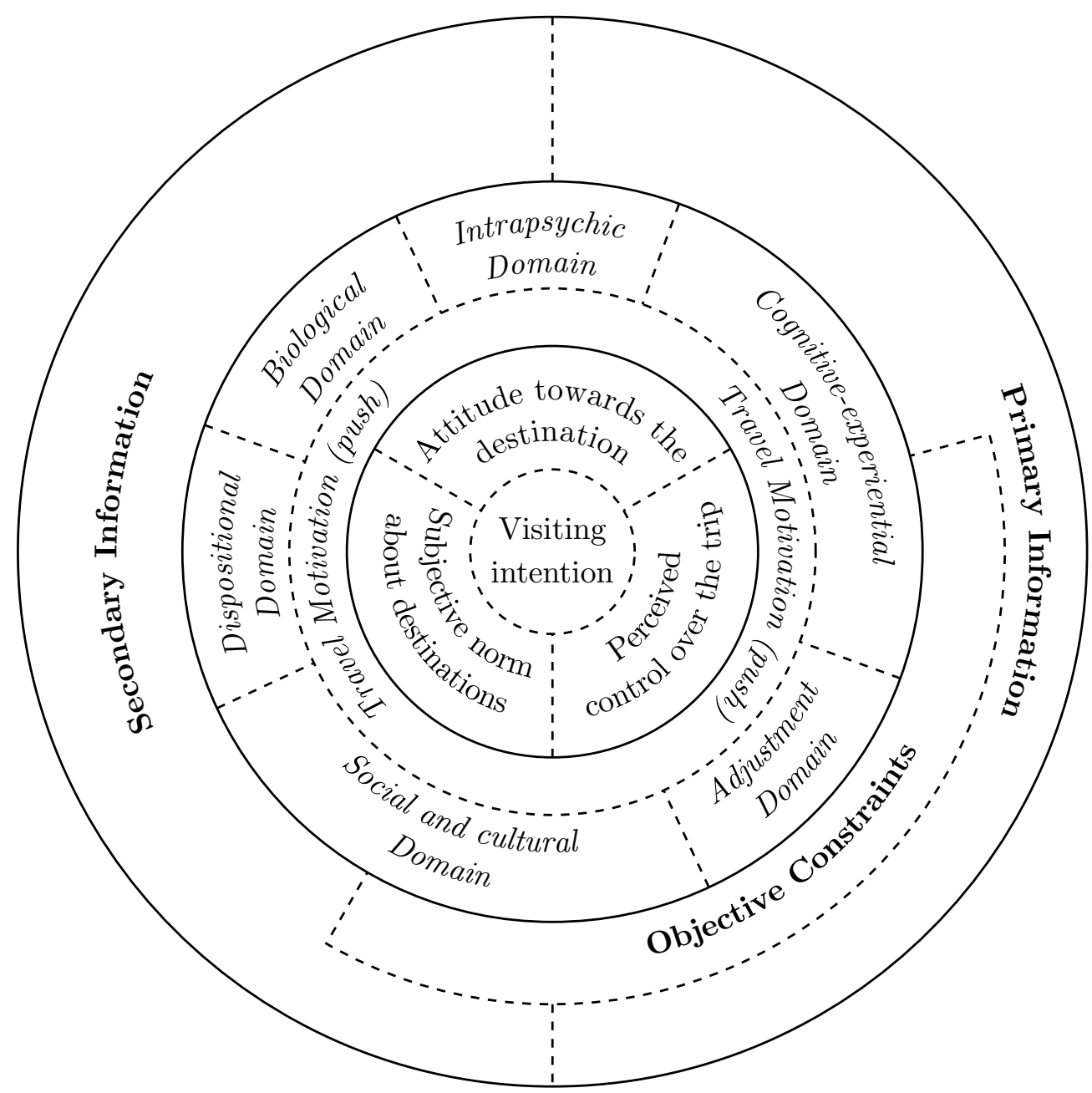

Figure 6. "Cell"

rience. By contrast, on a short-run basis, objective factors may influence trip-specific subjective factors, such as travel motivation. Among British and German tourists visiting Mallorca and Turkey, Kozak (2002) provided evidence of the differences in the set of tourist motivations between nationalities and between destinations. For visitors staying at hotels and resorts in Barbados, nationality and age were found to influence tourist intention to visit Jönsson and Devonish (2008). The final form of the "cell" is illustrated in Figure 6. The "cell", which is an evaluation tool, will be used in the "system" for destination choice mechanism. 


\section{The "System"}

The process of destination choice relates to the evaluation and comparison of visit intentions for all potential destinations.

According to the choice set framework, destination choice process is composed of three core stages (Crompton, 1992): the formation of available awareness set, the reduction to the relevant set, and the selection of final destination. Tourists first reject all destinations unavailable to them because of certain objective constraints. Among all available destinations, tourists decide the destinations for which further information is acquired. The final destination is then selected among these information-updated destinations.

In the first stage, the formation of available awareness set, which is a belief formation on aware destinations, is conducted to determine availability. This process reveals knowledge but not the intention (Decrop, 2010). The evaluation of availability may not cover all aware destinations before the decision unit proceeds to the next stage (Decrop, 2010). The process of constructing an available awareness set is usually passive and sometimes unconscious (Um \& Crompton, 1990). Thus, this process is sometimes excluded from the entire decision-making process (Laroche, Kim, \& Matsui, 2003). However, as noted by some marketing experts, "brand awareness is a necessary precondition for choice" (Nedungadi, 1990, p. 264).

The formal decision process of a specific trip starts once the formation of the relevant set is initiated (Um \& Crompton, 1990). Compared with the belief formation in the first stage, information search and information processing in the second stage are more active (Um \& Crompton, 1990). The formation of the relevant set is usually dynamic, changes with time and occasion, and intended by consumers (Shocker, Ben-Akiva, Boccara, \& Nedungadi, 1991). Relevant sets are usually small with means of 1.9, 2.6, 2.7, 4.2, and 3.4 destinations, as reported in Decrop (2010), Perdue and Meng (2006), Thompson and Cooper (1979), Woodside and Lysonski (1989), and Woodside and Sherrell (1977), respectively.

The selection process in the final stage involves evaluation of potential travel destinations and comparison among the evaluated values of potential travel destinations. 
This selection process is consistent with the utility maximization process described in economic choice behaviors, where utilities are calculated for all available options and the option with the highest utility is chosen (Harris, Driver, \& Bergersen, 1985).

The following example describes the three aforementioned stages which are graphically illustrated in Figure 7. The solid circle around each destination reflects the visit intention evaluated by individuals (i.e. "cell"). The dashed circle provides a break-even level distinguishing positive and negative feelings on a destination. Hence, individuals have a positive feeling toward a destination if the solid circle is larger than the dashed one and have a negative feeling otherwise.

We assume $\mathrm{Ms} \mathrm{Wu}$ is a Chinese citizen who plans a relaxing two week vacation at one of the Southeast Asian countries. Not being an experienced traveler, $\mathrm{Ms} \mathrm{Wu}$ is not aware of the existence of two Southeast Asian countries, Timor-Leste and Palau. Her awareness set, therefore, only contains 10 of the Southeast Asian countries, i.e. Brunei (BN), Cambodia (KH), Indonesia (ID), Laos (LA), Malaysia (MY), Myanmar (MM), Philippines (PH), Singapore (SG), Thailand (TH), and Vietnam (VN). Some constraints apply to the initial stage of the evaluation of potential destinations. In addition to time and money, other constraints may apply to specific trips. Travel composition, such as families with babies, seniors, or disabled people, can sometimes restrict tourists from certain destinations, such as undeveloped destinations with less barrier-free accessible facilities (Cavinato \& Cuckovich, 1992; Zimmer et al., 1995). Diseases can also restrict tourists from a certain area (e.g. Dehnert \& Bärtsch, 2010). In the example, since Chinese citizens need a visa to travel to the Philippines, Ms $\mathrm{Wu}$ removes the Philippines from the list immediately. Based on the existing information, the remaining nine destinations are evaluated according to the "cell". Indonesia and Singapore receive negative evaluations due to the recent news of anti-Chinese violence (i.e. secondary information) and an unpleasant previous trip (i.e. primary information), respectively. Brunei and Myanmar, as Ms Wu knows little about them, are marked neutral. These four destinations form the inept set (Indonesia and Singapore) and inert set (Brunei and Myanmar), respectively. Destinations with positive feelings (Cambodia, Laos, Malaysia, Thailand, and Vietnam) comprise the relevant set. Since relaxation is the primary motivation of the trip, the evaluations of the destinations 
are ranked according to their "degree of loosening" perceived by Ms Wu.

An information search is conducted to further evaluate and compare the destinations in the relevant set. In this stage, the break-even levels of information-updated destinations decrease due to the investment of resources (Crompton, 1992). The extensive information search leads to a revised assessment of the availability of certain destinations and traveler's visit intentions. In the example, Ms Wu finds out that, in order to get the free entry into Vietnam, she needs a registration from a travel agency, which cannot happen within days. On the other hand, Thailand, initially perceived as a cultural intense destination, is also a great place for relaxation. Vietnam, therefore, joins the unavailable awareness set and Thailand receives a significant increase in visit intention. According to the theory of rational inattention (Sims, 2003), information search may not cover each destination in the relevant set and some destinations are moved into the inaction set because of the limited information processing capacity (e.g., Laos and Cambodia). The information search ends when Ms Wu considers the result as "good enough" (Smallman \& Moore, 2010). The remaining destinations (Malaysia and Thailand) are referred to as the action set. The final destination (Thailand) is then selected after a comparison of the revised visit intentions for the destinations in the action set.

\section{Conclusions}

This paper intends to describe the psychological process of travel destination choice starting from a systematic review of the current literature. A "cell-system" structure is proposed to illustrate an evaluation-comparison process. An argument is put forth that tourists form visit intentions by evaluating subjective and objective factors at each stage of the destination choice process. Tourists are also assumed to update on visit intentions at each stage when extra information is acquired. A "good enough" destination is eventually selected by comparing visit intentions. A joint but distinct influence from personality and motivation is also proposed in the "cell" structure.

The main objective of the paper is to propose the "cell-system" structure and the studies included are perceived by the authors to best represent each link in the struc- 


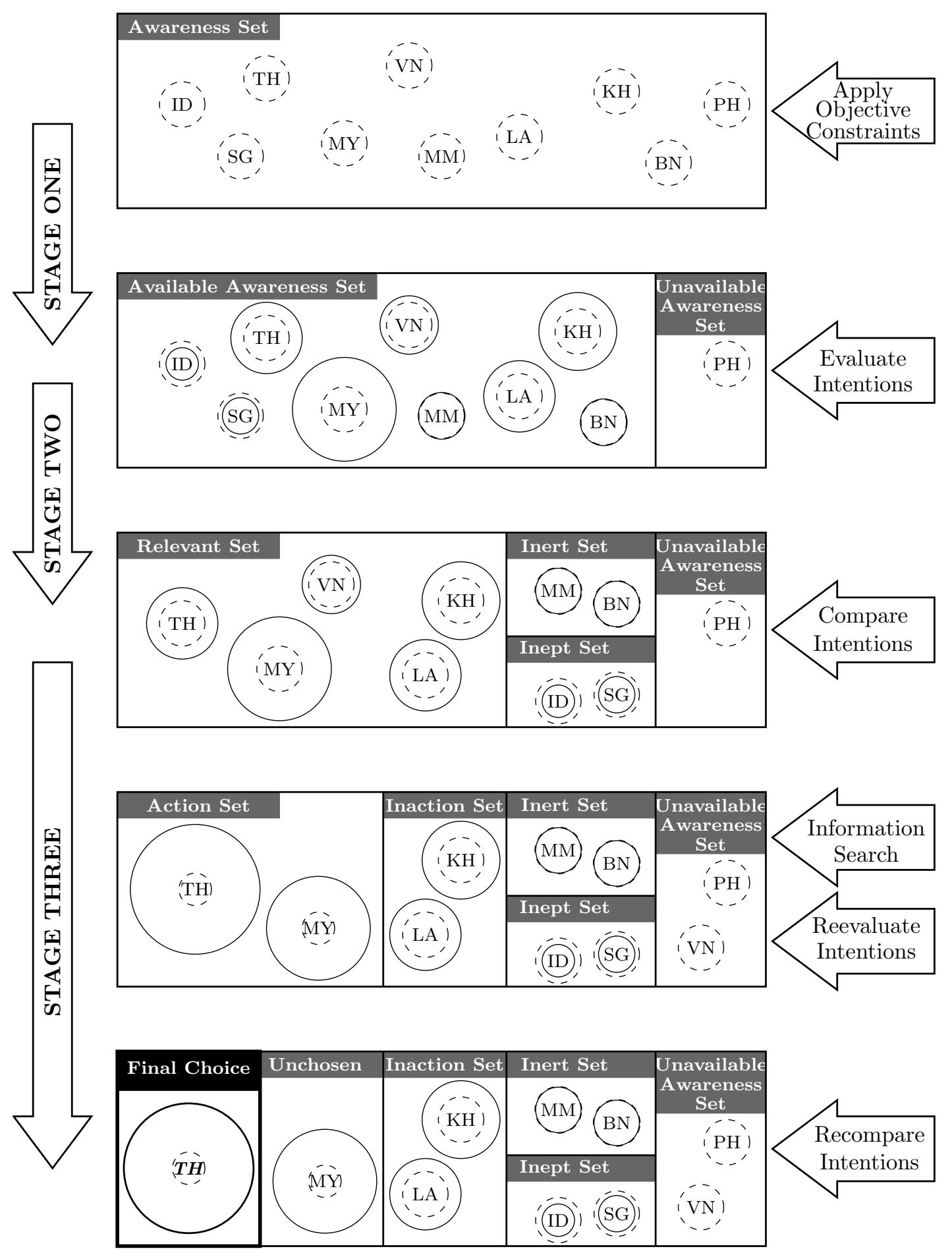

Figure 7. "System" 
ture. Being able to show the influences and interactions of various factors, the "cellsystem" structure can potentially resolve the contradicting results from different empirical studies (e.g., the effect of cultural distance on tourism demand from Ahn and McKercher (2015) and Ng et al. (2007)).

The "cell-system" structure also provides a base for practical contributions to the destination choice literature by facilitating a deeper analysis of those variables that influence the destination choice formation. However, pooling the results from studies with different background settings and sample sets cannot provide empirical evidence to support the existence of each link in the proposed structure. A large project that contains each element of the "cell-system" structure, although may be excessively large to easily achieve, can provide additional insights on the psychological process of destination choice. A comprehensive dataset on each subjective and objective factor would be necessary to test the evaluation phase, that is, the "cell" structure. A longitudinal study that involves data collection from different time periods would be needed to describe and empirically test the different stages of the comparison phase, which is the "system" structure. 


\section{References}

Ahn, M. J. \& McKercher, B. (2015). The effect of cultural distance on tourism: A study of international visitors to Hong Kong. Asia Pacific Journal of Tourism Research, 20(1), 94-113.

Ajzen, I. (1985). From intentions to actions: A theory of planned behavior. In Action Control (pp. 11-39). Springer.

Ajzen, I. \& Driver, B. L. (1992). Application of the theory of planned behavior to leisure choice. Journal of Leisure Research, 24(3), 207.

Anderson, B. B. \& Langmeyer, L. (1982). The under-50 and over-50 travelers: A profile of similarities and differences. Journal of Travel Research, 20(4), 20-24.

Awaritefe, O. (2004). Motivation and other considerations in tourist destination choice: A case study of Nigeria. Tourism Geographies, 6(3), 303-330.

Beerli, A. \& Martin, J. D. (2004). Factors influencing destination image. Annals of Tourism Research, 31(3), 657-681.

Best Trip Choices. (2017). http://besttripchoices.com/. Accessed: 03/03/2017.

Brisoux, J. E. \& Laroche, M. (1980). A proposed consumer strategy of simplification for categorizing brands. In J. D. Summey \& R. D. Taylor (Eds.), Evolving marketing thought for the 1980s. Proceedings of the Southern Marketing Association Annual Meeting. Carbondale, IL: Southern Marketing Association.

Cavinato, J. L. \& Cuckovich, M. (1992). Transportation and tourism for the disabled: An assessment. Transportation Journal, 46-53.

Chen, L. J. \& Chen, W. P. (2015). Push-pull factors in international birders' travel. Tourism Management, 48, 416-425.

Church, N. J., Laroche, M., \& Blatt, J. A. R. (1985). Consumer brand categorization for durables with limited problem solving: An empirical test and proposed extension of the Brisoux-Laroche model. Journal of Economic Psychology, 6(3), $231-253$.

Cohen, E. (1972). Toward a sociology of international tourism. Social Research, 164182. 
Crompton, J. L. (1979). Motivations for pleasure vacation. Annals of Tourism Research, 6(4), 408-424.

Crompton, J. L. (1992). Structure of vacation destination choice sets. Annals of Tourism Research, 19(3), 420-434.

Crompton, J. L. \& Ankomah, P. K. (1993). Choice set propositions in destination decisions. Annals of Tourism Research, 20(3), 461-476.

Dann, G. M. (1977). Anomie, ego-enhancement and tourism. Annals of Tourism Research, 4(4), 184-194.

Dann, G. M. (1981). Tourist motivation an appraisal. Annals of Tourism Research, $8(2), 187-219$.

Decrop, A. (2010). Destination choice sets: An inductive longitudinal approach. Annals of Tourism Research, 37(1), 93-115.

Dehnert, C. \& Bärtsch, P. (2010). Can patients with coronary heart disease go to high altitude? High Altitude Medicine 83 Biology, 11(3), 183-188.

Dykins, R. A. (2016). Shaping the future of luxury travel: Future traveler tribes 2030.

Eachus, P. (2004). Using the Brief Sensation Seeking Scale (BSSS) to predict holiday preferences. Personality and Individual Differences, 36(1), 141-153.

Echtner, C. M. \& Ritchie, J. B. (1993). The measurement of destination image: An empirical assessment. Journal of Travel Research, 31(4), 3-13.

Eymann, A. \& Ronning, G. (1997). Microeconometric models of tourists' destination choice. Regional Science and Urban Economics, 27(6), 735-761.

Eymann, A., Ronning, G., \& Zimmermann, K. F. (1992). Discrete choice analysis of foreign travel demand. In European Integration in the World Economy (pp. 641674). Springer.

Fishbein, M. \& Ajzen, I. (1977). Belief, attitude, intention, and behavior: An introduction to theory and research.

Font, A. R. (2000). Mass tourism and the demand for protected natural areas: A travel cost approach. Journal of Environmental Economics and Management, $39(1), 97-116$.

Fuchs, G. \& Reichel, A. (2006). Tourist destination risk perception: The case of Israel. Journal of Hospitality $\&$ Leisure Marketing, 14(2), 83-108. 
Gorman, W. M. (1957). Convex indifference curves and diminishing marginal utility. The Journal of Political Economy, 40-50.

Gorman, W. M. (1980). A possible procedure for analyzing quality differentials in the egg market. The Review of Economic Studies, 47(5), 843-856.

Gray, H. P. (1970). International Travel-International Trade. Heath Lexington Books.

Gretzel, U., Mitsche, N., Hwang, Y.-H., \& Fesenmaier, D. R. (2004). Tell me who you are and I will tell you where to go: Use of travel personalities in destination recommendation systems. Information Technology \& Tourism, 7(1), 3-12.

Griffith, D. A. \& Albanese, P. J. (1996). An examination of Plog's psychographic travel model within a student population. Journal of Travel Research, 34(4), 47-51.

Hamilton, J. M. (2004). Climate and the destination choice of German tourists. FEEM Working Paper.

Han, H., Hsu, L. T. J., \& Sheu, C. (2010). Application of the theory of planned behavior to green hotel choice: Testing the effect of environmental friendly activities. Tourism Management, 31(3), 325-334.

Harris, C. C., Driver, B. L., \& Bergersen, E. P. (1985). Do choices of snort fisheries reflect antler preferences for site attributes? In Proceedings symposium on recreation choice behavior (pp. 46-54). Missoula MT.: USDA Forest Service General Technical Report (INT-184).

Hsu, T. K., Tsai, Y. F., \& Wu, H. H. (2009). The preference analysis for tourist choice of destination: A case study of Taiwan. Tourism Management, 30(2), 288-297.

Huybers, T. (2003). Domestic tourism destination choices-a choice modelling analysis. The International Journal of Tourism Research, 5(6), 445.

Iso-Ahola, S. E. \& Weissinger, E. (1990). Perceptions of boredom in leisure: Conceptualization, reliability and validity of the leisure boredom scale. Journal of Leisure Research, 22(1), 1.

Jacobsen, J. K. S. (2016). Graham MS Dann: The peripatetic who was pushed and pulled. Anatolia, 27(1), 111-119.

Jalilvand, M. R. \& Samiei, N. (2012). The impact of electronic word of mouth on a tourism destination choice: Testing the theory of planned behavior (TPB). 
Internet Research: Electronic Networking Applications and Policy, 22(5), 591612.

Jalilvand, M. R., Samiei, N., Dini, B., \& Manzari, P. Y. (2012). Examining the structural relationships of electronic word of mouth, destination image, tourist attitude toward destination and travel intention: An integrated approach. Journal of Destination Marketing $\& 3$ Management, 1(1), 134-143.

Jang, S. C. \& Cai, L. A. (2002). Travel motivations and destination choice: A study of British outbound market. Journal of Travel \&5 Tourism Marketing, 13(3), 111133.

Jani, D. (2014). Relating travel personality to Big Five Factors of personality. Turizam: Znanstveno-stručni časopis, 62 (4), 347-359.

Jönsson, C. \& Devonish, D. (2008). Does nationality, gender, and age affect travel motivation? A case of visitors to the Caribbean island of Barbados. Journal of Travel \& Tourism Marketing, 25(3-4), 398-408.

Karl, M., Reintinger, C., \& Schmude, J. (2015). Reject or select: Mapping destination choice. Annals of Tourism Research, 54, 48-64.

Kim, S. S., Im, H. H., \& King, B. E. (2015). Muslim travelers in Asia the destination preferences and brand perceptions of Malaysian tourists. Journal of Vacation Marketing, 21(1), 3-21.

Kim, S. S., Wan, Y. K. P., \& Pan, S. (2015). Differences in tourist attitude and behavior between Mainland Chinese and Taiwanese tourists. Journal of Travel E Tourism Marketing, 32(1-2), 100-119.

Kozak, M. (2002). Comparative analysis of tourist motivations by nationality and destinations. Tourism Management, 23(3), 221-232.

Lam, T. \& Hsu, C. H. (2004). Theory of planned behavior: Potential travelers from China. Journal of Hospitality \& Tourism Research, 28(4), 463-482.

Lam, T. \& Hsu, C. H. (2006). Predicting behavioral intention of choosing a travel destination. Tourism Management, 27(4), 589-599.

Lancaster, K. J. (1966). A new approach to consumer theory. The Journal of Political Economy, 132-157. 
Lancaster, K. J. (1971). Consumer demand: A new approach. Columbia University Press New York.

Laroche, M., Kim, C., \& Matsui, T. (2003). Which decision heuristics are used in consideration set formation? Journal of Consumer Marketing, 20(3), 192-209.

Larsen, R. J. \& Buss, D. M. (2013). Personality psychology: Domains of knowledge about human nature (5th ed.). McGraw-Hill Education.

Leary, M. R. (1983). Social anxiousness: The construct and its measurement. Journal of Personality Assessment, 47(1), 66-75.

Lee, G. \& Tussyadiah, I. P. (2012). Exploring familiarity and destination choice in international tourism. Asia Pacific Journal of Tourism Research, 17(2), 133145.

Lee, T. H. \& Crompton, J. L. (1992). Measuring novelty seeking in tourism. Annals of Tourism Research, 19(4), 732-751.

Lepp, A. \& Gibson, H. (2008). Sensation seeking and tourism: Tourist role, perception of risk and destination choice. Tourism Management, 29(4), 740-750.

Leung, R. \& Law, R. (2010). A review of personality research in the tourism and hospitality context. Journal of Travel $\& 3$ Tourism Marketing, 27(5), 439-459.

Litvin, S. W. (2006). Revisiting Plog's model of allocentricity and psychocentricity... one more time. Cornell Hotel and Restaurant Administration Quarterly, 47(3), $245-253$.

Maddi, S. R., Charlens, A. M., Maddi, D.-A., \& Smith, A. J. (1962). Effects of monotony and novelty on imaginative productions. Journal of Personality, 30(4), $513-527$.

Madrigal, R. (1995). Personal values, traveler personality type, and leisure travel style. Journal of Leisure Research, 27(2), 125.

Mansfeld, Y. (1992). From motivation to actual travel. Annals of Tourism Research, $19(3), 399-419$.

McCrae, R. R. \& Costa, P. T. (1994). The stability of personality: Observations and evaluations. Current Directions in Psychological Science, 3(6), 173-175.

Mehrabian, A. \& Russell, J. A. (1973). A measure of arousal seeking tendency. Environment and Behavior, 5(3), 315. 
Mohammad, B. A. M. A.-H. \& Som, A. P. M. (2010). An analysis of push and pull travel motivations of foreign tourists to jordan. International Journal of Business and Management, 5(12), 41.

Morey, E. R., Shaw, W. D., \& Rowe, R. D. (1991). A discrete-choice model of recreational participation, site choice, and activity valuation when complete trip data are not available. Journal of Environmental Economics and Management, 20(2), $181-201$.

Moscardo, G., Dann, G., \& McKercher, B. (2014). Do tourists travel for the discovery of "self" or search for the "other"? Tourism Recreation Research, 39(1), 81-106.

Moscardo, G., Morrison, A. M., Pearce, P. L., Lang, C. T., \& O’Leary, J. T. (1996). Understanding vacation destination choice through travel motivation and activities. Journal of Vacation Marketing, 2(2), 109-122.

Narayana, C. L. \& Markin, R. J. (1975). Consumer behavior and product performance: An alternative conceptualization. The Journal of Marketing, 1-6.

Nedungadi, P. (1990). Recall and consumer consideration sets: Influencing choice without altering brand evaluations. Journal of Consumer Research, 17(3), 263-276.

Ng, S. I., Lee, J. A., \& Soutar, G. N. (2007). Tourists' intention to visit a country: The impact of cultural distance. Tourism Management, 28(6), 1497-1506.

Nichols, C. M. \& Snepenger, D. J. (1988). Family decision making and tourism behavior and attitudes. Journal of Travel Research, 26(4), 2-6.

Nickerson, N. P. \& Ellis, G. D. (1991). Traveler types and activation theory: A comparison of two models. Journal of Travel Research, 29(3), 26-31.

Nicolau, J. L. \& Más, F. J. (2006). The influence of distance and prices on the choice of tourist destinations: The moderating role of motivations. Tourism Management, $27(5), 982-996$.

Papatheodorou, A. (2001). Why people travel to different places. Annals of Tourism Research, 28(1), 164-179.

Papatheodorou, A. (2002). Exploring competitiveness in Mediterranean resorts. Tourism Economics, 8(2), 133-150.

Pearson, P. H. (1970). Relationships between global and specified measures of novelty seeking. Journal of Consulting and Clinical Psychology, 34(2), 199. 
Perdue, R. R. \& Meng, F. (2006). Understanding choice and rejection in destination consideration sets. Tourism Analysis, 11(6), 337-348.

Plog, S. C. (1974). Why destination areas rise and fall in popularity. Cornell Hotel and Restaurant Administration Quarterly, 14(4), 55-58.

Plog, S. C. (1995). Vacation places rated. Redondo Beach: Fielding Worldwide.

Plog, S. C. (2001). Why destination areas rise and fall in popularity: An update of a Cornell Quarterly classic. Cornell Hotel and Restaurant Administration Quarterly, 42(3), 13-24.

Pomfret, G. (2006). Mountaineering adventure tourists: A conceptual framework for research. Tourism Management, 27(1), 113-123.

Ritchie, J. B. \& Filiatrault, P. (1980). Family vacation decision-making-a replication and extension. Journal of Travel Research, 18(4), 3-14.

Rotter, J. B. (1966). Generalized expectancies for internal versus external control of reinforcement. Psychological Monographs: General and Applied, 80(1), 1.

Seddighi, H. R., Nuttall, M., \& Theocharous, A. L. (2001). Does cultural background of tourists influence the destination choice? An empirical study with special reference to political instability. Tourism Management, 22(2), 181-191.

Seddighi, H. R. \& Theocharous, A. L. (2002). A model of tourism destination choice: A theoretical and empirical analysis. Tourism Management, 23(5), 475-487.

Shocker, A. D., Ben-Akiva, M., Boccara, B., \& Nedungadi, P. (1991). Consideration set influences on consumer decision-making and choice: Issues, models, and suggestions. Marketing Letters, 2(3), 181-197.

Siderelis, C. \& Moore, R. L. (1998). Recreation demand and the influence of site preference variables. Journal of Leisure Research, 30(3), 301.

Sims, C. A. (2003). Implications of rational inattention. Journal of Monetary Economics, 50(3), 665-690.

Smallman, C. \& Moore, K. (2010). Process studies of tourists' decision-making. Annals of Tourism Research, 37(2), 397-422.

Sönmez, S. F. \& Graefe, A. R. (1998a). Determining future travel behavior from past travel experience and perceptions of risk and safety. Journal of Travel Research, $37(2), 171-177$. 
Sönmez, S. F. \& Graefe, A. R. (1998b). Influence of terrorism risk on foreign tourism decisions. Annals of Tourism Research, 25(1), 112-144.

Specht, J., Egloff, B., \& Schmukle, S. C. (2011). Stability and change of personality across the life course: The impact of age and major life events on mean-level and rank-order stability of the Big Five. Journal of Personality and Social Psychology, 101(4), 862.

Stabler, M. J., Papatheodorou, A., \& Sinclair, M. T. (2009). The economics of tourism. Routledge.

Stemerding, M., Oppewal, H., \& Timmermans, H. (1999). A constraints-induced model of park choice. Leisure Sciences, 21(2), 145-158.

Swarbrooke, J. \& Horner, S. (2003). Consumer behavior in tourism. Great Britain: Martins the Printers, Berwick upon Tweed.

Tham, A., Croy, G., \& Mair, J. (2013). Social media in destination choice: Distinctive electronic word-of-mouth dimensions. Journal of Travel $\&$ Tourism Marketing, $30(1-2), 144-155$.

Thompson, J. R. \& Cooper, P. D. (1979). Additional evidence on the limited size of evoked and inept sets of travel destinations. Journal of Travel Research, 17(3), $23-25$.

Thornton, P. R., Shaw, G., \& Williams, A. M. (1997). Tourist group holiday decisionmaking and behaviour: The influence of children. Tourism Management, 18(5), $287-297$.

Train, K. E. (1998). Recreation demand models with taste differences over people. Land Economics, 230-239.

Um, S. \& Crompton, J. L. (1990). Attitude determinants in tourism destination choice. Annals of Tourism Research, 17(3), 432-448.

Wentworth, N. \& Witryol, S. L. (1986). What's new? Three dimensions for defining novelty. The Journal of Genetic Psychology, 147(2), 209-218.

Woodside, A. G. \& Lysonski, S. (1989). A general model of traveler destination choice. Journal of Travel Research, 27(4), 8-14.

Woodside, A. G. \& Sherrell, D. (1977). Traveler evoked, inept, and inert sets of vacation destinations. Journal of Travel Research, 16(1), 14-18. 
Wu, L., Zhang, J., \& Fujiwara, A. (2011). Representing tourists' heterogeneous choices of destination and travel party with an integrated latent class and nested logit model. Tourism Management, 32(6), 1407-1413.

Yoon, Y. \& Uysal, M. (2005). An examination of the effects of motivation and satisfaction on destination loyalty: A structural model. Tourism Management, 26(1), $45-56$.

Zimmer, Z., Brayley, R. E., \& Searle, M. S. (1995). Whether to go and where to go: Identification of important influences on seniors' decisions to travel. Journal of Travel Research, 33(3), 3-10.

Zuckerman, M. (1971). Dimensions of sensation seeking. Journal of Consulting and Clinical Psychology, 36(1), 45.

Zuckerman, M. (1979). Sensation seeking. Wiley Online Library.

Zuckerman, M., Eysenck, S. B., \& Eysenck, H. J. (1978). Sensation seeking in England and America: Cross-cultural, age, and sex comparisons. Journal of Consulting and Clinical Psychology, 46(1), 139.

Zuckerman, M., Kolin, E. A., Price, L., \& Zoob, I. (1964). Development of a sensationseeking scale. Journal of Consulting Psychology, 28(6), 477. 